\title{
KELET-AUSZTRIA AZ ÚJ KÖZÉP-EURÓPÁBAN A JÖVÖKÉP ÉS AZ INTÉZMÉNYRENDSZER KÉRDÉSEI
}

\author{
(East Austria in the New Central Europe - Prospects and \\ Institutional System)
}

\section{FÁTH JÁNOS}

A nyugat- és közép-kelet-európai fejlődés Ausztriát új helyzet elé állította. A "helyzet" nem is fejezi ki az eredményt, mert a fogalom statikus állapotra utal. Ezzel szemben éppen a dinamikus változás az uralkodó jelenség. Az Európai Unió többek között - egy nagy regionális piac is, amelyen kis- és nagyvállalatoknak egyaránt szigorúan szabályozott versenyhelyzetben kell a fennmaradásért megkuzdeniük. A többé-kevésbé nyiltt vagy rejtett piaci védelem, amelyet egyes szektorok élveztek, megszủnőben van.

A regionális piac sem védett piac: a szereplőknek egy globális versenyben is helyt kell állni. Ebben az összefüggésben az Európai Unió országai is mutatnak fel merevségeket, protekcionista vonásokat, amelyek fokozatosan feladásra kerülnek. Az Egyesült Államok, Japán, Kína és az ázsiai tigrisek versenyében nem biztos, hogy - kissé leegyszerúsítő kifejezéssel élve - az EU lesz a 21. században a "nyertes" (Thurow 1996).

Ausztria közvetlen szomszédságában található a közép-kelet-európai térség. Az osztrák határ egyben az EU határa is. Ez különleges kötelezettséget ró az országra és ezen belül a keleti térségeire. Ausztria kivitelének 13\%-a irányul a kelet-középeurópai országokba. Becslések szerint ez 20\%-ra is emelkedhet a közeli években.

Ezeknek a változásoknak egyik fejleménye, hogy az új nemzetközi "kihívások" és lehetőségek az országos kérdésfelvetések mellett az egyes országrészek, tartományok önvizsgálatát is erősítették. Az Európai Unió regionális politikája támogatja a gyengébben fejlett régiókat - ezáltal a gyengébbek versenyhelyzetét erősíteni igyekszik. Az "erősek" versenyhelyzete sem végleges, azt meg kell védeni, sőt tovább kell építeni. Van-e meghatározás a régiók versenyképességére? Mik annak a meghatározó tényezői?

A válaszadás egyik módja, hogy a régiók megállapítják erősségeiket és gyengeségeiket, majd megkísérelnek egy helyzetképet és egy jövőképet kialakítani. A képnek reálisnak kell lennie, egyben arra szolgál, hogy annak alapján döntéseket, rendszabályokat hozzanak vagy arra, hogy a régió gazdasági szereplőit informálja a régió előnyeiről - többek között - a régión kívülieket is meggyőzze (marketing). Erre szüksége lehet a régión belüli szereplöknek is. A jövőkép pedig nem terv, még csak nem is feltétlenül konkrét stratégia, hanem a jövőnek egy modellje, aminek elérésére a régió törekedhet. Ez attól is függ, hogy a jövőkép tekintélye (szakmai- 
Fáth János : Kelet-Ausztria az új Közép-Európában.

A jövőkép és az intézményrendszer kérdései.

Tér és Társadalom 11. évf. 1997/1. 271-281. p.

tudományos megalapozottsága) és politikai legitimációja (a mögötte álló intézményi erök súlya) milyen.

A jövőkép a belsö erök és a környezeti változások figyelembevételével határozza meg a régió jövőbeli helyzetét, annak jellemzöit. A jövöképek gyakran csak részterületekre vonatkoznak, esetleg célbavett pénzügyi források mozgósitását célozzák.

A régiók eszköztára azonban korlátozott, intézményrendszerük is fejlesztésre szorul. Az is kitünhet, hogy egyes feladatokat nem más régióktól elhatároltan, hanem azokkal együtt kell megoldani. A közös cselekvés szándéka és képessége szabja meg a regionális együttmüködés határait. Ezek nélkül a régió vagy a régiók valamilyen közös képe csak elképzelés, tudományos feltételezés. Ez kiegészülhet azzal, hogy a határmenti régiók keresik a lehetőségeiket, valamint a formát a határon átnyúló kooperációkra, amit megfelelő intézményrendszer támaszthat alá. Itt az intézményrendszeren nem bürokratizálódást kell érteni. Sőt a regionális és interregionális együttmüködésben érdekelt erők gyakran a civil összefogásban, az érdekeltek, a lakosság széleskörủ bevonásában/aktivizálásában látják az optimális megoldási lehetöségeket. A regionális érdek sem egyszerúen definiálható: részérdekek állhatnak szemben egymással, blokkolhatnak akciókat, ösztönözhetnek elzárkózó magatartásra.

Az Európai Közösségben, de globális összefüggésben is, nemcsak vállalatok, hanem a régiók is versenyben állnak egymással. A régiók versenyben vannak országon belül és nemzetközi szinten is. A jelen és a jövőkép feladata a versenyképesség reális és meggyőző feltárása, bemutatása.

Fontos azonban a kérdés helyes felvetése. Porter (1992) után szólva, a kérdés az, hogy egy nemzet/régió hogyan hoz létre olyan környezetet, amelyben a vállalatok gyorsabban fejlődnek és újítanak egy adott ágazatban mint más országbeli (analógia alapján: régióbeli) versenytársaik. Porter az adott termelési tényezök statikus értelmezése helyett azt hangsúlyozza, hogy vállalatok, nemzetek (mi esetünkben régiók) hogyan javítják a termelési tényezők minőségét, hogyan hasznosítják azokat és hogyan teremtenek újakat. Ebben a hangsúly az innováción van, az állandó minőségi megújuláson. Ebben a vállalati kezdeményezés és a hazai bázis ösztönző/mozgósító befolyásának, kölcsönhatásának van döntő jelentősége.

A regionális versenyképesség egy speciális megközelítése a skandináv/angolszász szóhasználaton alapul: a "C" társadalmat, a "C" régió gondolata helyezi előtérbe, gyakorlati alkalmazásra (Huber 1993). A betú itt a communication, computer technology, competence, creativity, culture területeit öleli fel. A regionális kutatás a jövőkép kialakítása céljából olyan jellemzöket keres, amelyek a legfejlettebb régiókban magas fokon és állandóan megújuló módon fellelhetök. Jellemzők, mint infrastruktúra, a népesség képzettsége, életforma és környezeti minöség, kutatás, innovációs dinamika, a beruházások szintje, a nagyvállalati/kis- és középvállalati struktúrák jelenléte és kapcsolatrendszere. A jól müködö közigazgatás mellett kiemelt tényezóként kezelik a kommunikációs képességet: a megegyezésre (konszenzusra) irányuló készséget és vita-kultúrát, a kooperációs készséget a régióban jelen lévő pártok elitjében, a jól müködő szakmai szervezeteket, a vállalatok, a tudomány és a média közötti kommunikációt, nyilvános vitákat a változásokkal kapcsolatos kockázatról. A regionális jövőkép - valamint annak 
Fáth János : Kelet-Ausztria az új Közép-Európában.

A jövőkép és az intézményrendszer kérdései.

Tér és Társadalom 11. évf. 1997/1. 271-281. p.

megvalósításához vezetö út - ilyen jellemzökre alapitott modellek alapján kritikusan és meggyőzően alakítható ki.

Ezek az elemek képezhetik regionális alapon együttesen azt a környezetet, amelyben versenyképes, dinamikus vállalatok keletkeznek és müködnek. A jelenkép: az adott környezet analitikus, összehasonlító leírása, a jövőkép: a meghatározott faktorok alapján kialakított célmodell.

\section{Ausztria keleti tartományai}

Statisztikailag szokásos Ausztriát világtájak szerint három területre osztani. Az ország kis kiterjedése miatt mindegyik terület egyben egy határvidékre is utal. A Keleti Régió jelentőségét az országban az 1. táblázat foglalja össze.

\section{TÁBLÁZAT \\ A Keleti Régió \\ The Eastern Region}

\begin{tabular}{|l|c|c|c|c|c|c|c|}
\hline \multirow{2}{*}{} & \multicolumn{2}{|c|}{ Terület } & \multicolumn{2}{c|}{ Lakosság } & $\begin{array}{c}\text { Nép- } \\
\text { súrüség }\end{array}$ & \multicolumn{2}{c|}{$\begin{array}{c}\text { Bruttó nemzeti } \\
\text { jövedelem (1991) }\end{array}$} \\
\cline { 2 - 8 } & $\mathrm{km}^{2}$ & $\%$ & fö & $\%$ & fó/km² & Mrd S & $\%$ \\
\hline Burgenland & 3965 & 4,7 & 273283 & 3,4 & 70 & 38,39 & 2,2 \\
\hline Alsó-Ausztria & 19174 & 22,9 & 1505236 & 8,8 & 79 & 279,82 & 16,1 \\
\hline Bécs & 415 & 0,5 & 1589052 & 19,9 & 3829 & 493,17 & 28,4 \\
\hline Keleti Régió & 23554 & 28,1 & 3367571 & 32,1 & 143 & 811,38 & 46,7 \\
\hline Ausztria ósszesen & 83564 & 100,0 & 7991485 & 100,0 & 95 & 1737,17 & 100,0 \\
\hline
\end{tabular}

Forrás: ÖSTAT, 1991.

Kelet-Ausztria helyzete a XX. században többszörösen ment át alapvetö változáson.

A legkisebb egység, Burgenland, az első világháború végéig Magyarország része volt. Egyes helységnevek ma is örzik (magyarul éppen úgy, mint németúl) a határvidék jelleget. Ebben az időben a gravitációs irány a mezőgazdasági jellegü települések számára Sopron, Szombathely, Györ és egyéb nyugat-magyarországi városok voltak (Schremmer/Krajasits 1992). A dualista Osztrák-Magyar Monarchia magyar része a Lajtáig terjedt.

Történelmileg más a helyzete Alsó-Ausztriának. Az egykori koronatartományok centrális részét képezte. Útvonalai, települései fontos kapcsolatot jelentettek FelsỏMagyarország és Cseh-Morvaország irányában. A Monarchia felbomlása után egyik alkotóeleme lett az új (akkor még nagyon bizonytalan jövöjü) osztrák államterületnek.

Alapvetöen változott meg Bécs helyzete. A Monarchia nagy metropolisa egy kis ország perifériájára szorult. Közjogi helyzete szerint föváros és tartomånyi státusa is 
Fáth János : Kelet-Ausztria az új Közép-Európában.

A jövőkép és az intézményrendszer kérdései.

Tér és Társadalom 11. évf. 1997/1. 271-281. p.

van. Ettöl eltekintve, lakosságszáma, intézményei és a kitermelt nemzeti jövedelem alapján is domináló helyzete van az országban.

Nemzetközi vonatkozásban Kelet-Ausztria éppen úgy, mint az egész ország a két világháború közötti időszakban is sokat megőrzött korábbi kulturális és gazdasági kapcsolataiból. A második világháborút követően a periféria-jelleg azonban a terület nagy részében még kifejezettebben uralkodóvá vált. A Keleti Régió nagy része 1955-ig szovjet megszállás alatt volt. A magyar és a csehszlovák határok - $1200 \mathrm{~km}$ hosszúságban - "holt határok"-nak számitottak, hátrányos kihatással a gazdasági és kulturális fejlődésre. A keleti határvidék fogalma visszamaradottsággal, elvándorlással, nyomasztó, sőt veszélyeket hordozó jelleggel kapcsolódott össze. A kis Ausztriában a lakosság több, mint 50\%-a él határvidéken (ÖROK 1975). 16\%-a a keleti határvidéken. Míg a nyugati határvidékek különösen 1955 után eröteljes fejlődésnek indultak, a keleti határvidékeken a fejlỏdés lassúbb volt. Erősödött a színvonalkülönbség a "nyugati" és a "keleti" tartományok között (Nyugat-Kelet lejtő).

\section{Tartományi helyzet-meghatározás és jövókép}

Az osztrák Keleti Régió népesedési, általános és ágazati gazdasági mutatói, mint trend- és mint színvonalmutatók figyelemre méltóak. Ösztönöznek a tágabb középeurópai régió gazdasági összefonódását elősegítő összehasonlitásokra, a gazdaság alakulásának közös megfigyelésére/elemzésére is.

Az egyes tartományok erősségeinek és gyengeségeinek az elemzésénél nagy súlyt kapnak az új geopolitikai helyzetből adódó változások. A nyugatról és keletről egyaránt erösödő versenyhelyzetben az első természetes reakció a meglévő állapotok konzerválására való törekvés volt. A vendégmunkások az iparban, a kézmủiparban, a mezőgazdaságban, az idegenforgalomban (a foglalkoztatottak a munkaerö $10-12 \%$-a) úgy is tekinthetök, mint ennek a konzerválási törekvésnek az egyik eszköze. A másik eszköz lehetne a politikailag aligha keresztülvihető bérszint befagyasztás/csökkentés. Ezzel a legfeljebb átmeneti jellegü, defenzív stratégiával szemben mind a gazdaság képviselöinek túlnyomó része, mind pedig a kutatók az offenziv-modernizáló, strukturális változásokat sürgető stratégia hivei és ennek megfelelö jövőképeken dolgoznak (Schremmer-Krajasits 1992, Geldner 1993).

Burgenland, mint EU Cel-1 terület gyengeséget eröteljes telepítési és fejlesztési tényezővé alakítja át. Egy felzárkózási stratégia keretében minőségi munkahelyeket, jól funkcionáló stratégiai ösztönzéseket kívánnak megvalósitani, korszerủ gyáripari üzemeket létesíteni és az idegenforgalmat erősíteni. Ebbe a fejlesztési elgondolásba illeszkednek a technológia-, ipari parkok, szakföiskolák, a határon átlépö kooperációk szorgalmazása.

Van azonban még egy igényesebb távlati megközelítés is: a fokozatos felzárkózás helyett egy fejlődési ugrás elemeinek a keresése. Ez a burgenlandi gazdasági struktúra alapvető, hosszúlejáratú megváltoztatását igényli. Itt Észak-Burgenlandnak a Bécs-Pozsony-Győr-Sopron régióhoz csatlakozó intenziv modernizálása, kiépítése, a gazdaságföldrajzi adottságokból eredő elönyök hatásos kihasználása a cél (Puchinger-Palme-Rosinak 1994). 
Fáth János : Kelet-Ausztria az új Közép-Európában.

A jövőkép és az intézményrendszer kérdései.

Tér és Társadalom 11. évf. 1997/1. 271-281. p.

Alsó-Ausztria egy före eső nemzeti jövedelme 16\%-kal az EU átlag alatt van. Így átmeneti helyet foglal el az EK legfejlettebb központi fekvésü térségei és a gyengébben fejlett perifériás régiók között. Erössége ma is az ipar. E szektor gyengeségei viszont nagy részben a hosszú időn keresztül védett státusra vezethetők vissza. Az innovációk, a müszaki fejlesztés nem kielégítỏ színvonala, a termeléshez közelálló szolgáltatások elmaradottságát jelzik a kutatók. A tartomány tercializálódása még nem zárult le. A foglalkoztatottak 57-58\%-a ugyan már ezekben az ágazatokban dolgozik, a nemzeti jövedelemhez való hozzájárulás tekintetében azonban még mindig az ipar a legjelentősebb.

Stratégiai elgondolások szerint Alsó-Ausztriának ki kell használnia azt az esélyt. hogy eddigi perifériális helyzetet egy nemcsak névleges vagy tisztán földrajzi, hanem gazdasági értelmezésben centrális közép-európai régióvá alakítsa át. Ehhez a földrajzi helyzet csak az egyik elöfeltétel. Az elgondolások szerint ehhez az alsóausztriai iparnak szorosan össze kell fonódnia a környező szomszédos országok gazdaságával a $400 \mathrm{~km}-\mathrm{t}$ kitevő keleti határon keresztül. Ehhez regionális orientációjú vállalati településekre lenne szükség. A tartomány iparának fontos kooperációs bedolgozói kapesolatokat kell kiépítenie az EK iparával. Vertikális kooperációkat kell kiépítenie a környező szomszédos országok ipari, kézmủipari vállalataival. Egyes gyártási ágazatokban a fejlesztés-innováció révén nemzetközileg megvédhetỏ specializálódási fokot kell elérni (Palme 1993).

Mindehhez különösen fontos feltétel a határon átnyúló struktúrák (közlekedés, szállítás, telekommunikáció, információs rendszerek) kiépítése. Alsó-Ausztria egyes városai városi stratégiájukban kifejezetten a Kelet-Közép-Európa felé irányuló kapu szerepét hangsúlyozzák. Egyes alsó-ausztriai intézmények és vállalatok - mint pld. az ECO PLUS Betriebsansiedlung und Regionalisierung Gmbh, Wien - hatásosan dolgoznak a szükséges infrastruktúrák megvalósításán, a vállalkozások támogatásán.

Bécs méretei, országos és nemzetközi jelentősége alapvetően meghatározzák a Keleti Régió jellemzőit. Bécs az ország területének 5,5\%-a, de az osztrák nemzeti jövedelem $28 \%$-át itt állítják elö. A város a kutatás, az ipar, az idegenforgalom centrális helye Ausztriában. A megítéléshez az is hozzátartozik, hogy ipari struktúrája gyengeségeket mutat, export-orientációja, innovációs szintje az országos átlag alatt van. Egyes külföldi felmérések Bécset a metropolisok nemzetközi versenyében kedvezötlenül rangsorolják.

Ezek a gyengeségek összefüggnek a város egykori közelségével a holt határokhoz, továbbá a hosszú időn át követett defenzív gazdasági politikával. A keleti nyitás és az EK csatlakozás módosítják a követendỏ játékszabályokat. A város számára új jövőképeket dolgoznak ki. A Bécs-Pozsony agglomerációban - a kapcsolódó régiókat hozzászámítva - 3,7 millió lakossal, ill. 1,9 millió munkahellyel egy nagy fejlődési potenciálú régió van kialakulóban (Krajasits 1992).

Bécs jövőbeli gazdasági szerepét illetően két elképzelés ismert.

Az egyik szerint Bécs, mint menedzsment és tranzakciós központ a nemzetközi (überregionális) kereskedelmi és szolgáltatási bázisként használja ki helyzetét a közép-európai régióban. Ehhez az kell, hogy megerösítse helyét a személyi, az áruforgalmi, az információs és kommunikációs áramlásban, támaszkodjék a piacok földrajzi-kulturális-tơrténelmi közelségére, továbbá jelenjen meg Bécs, mint nemzetközi nagyvállalatok (multinacionális) regionális központja. 
A másik jövőkép modell szerint Bécsnek meg kell újítania ipari központ szerepét, a bécsi nagytérséget Közép-Európa központi ipari régiójává kell kifejleszteni. A lényege: egy határon átnyúló, nemzetközileg is versenyképes vállalati (termelési) hálózat kialakítása, a régió gazdaságainak integrációjának elösegítésével és hálózatszerú összekapcsolásával. A célok szükségessé teszik a Keleti Régióban a határon átnyúló tevékenységek intézményi feltételeinek a megvalósítását, fontosabb fejlesztési kérdések (közlekedés, területfejlesztés, támogatási politika, telephelymarketing) összehangolását, a közös megoldások keresését (Mayerhofer 1992, 1994, Magistrat der Stadt Wien, Step 1994).

A második modell döntő sajátossága, hogy kitekintő jellegü: a régiók (tartományok) kívánt fejlődését a környezö (bel- és külföldi) régiókkal történő együttes változásokon, egymással összefưggő feltételrendszerek megvalósitásán keresztül tartja csak elérhetőnek.

\section{A Keleti Régió ủj geopolitikai helyzete}

A "határnyitás" és a politikai rendszerváltás új feltételeket teremtettek Ausztria és föleg Kelet-Ausztria geopolitikai helyzetében. Az első öröm után az emberek - a társadalomban és fóleg a gazdaságban elfoglalt helyük szerint - nagyon különbözően reagáltak a változásokra. A várakozásokban félelmek (munkaerővándorlás, alacsonybérü szomszédos országok versenye, munkahelyvesztés, vásárlóturizmus, ipari üzemek elvándorlása) éppúgy jelentkeztek, mint az új lehetőségek felismerése (Aiginger 1993). Tudatossá vált, hogy a kelet-európai rendszerváltozás gyorsítani fog olyan strukturális változásokat, amelyek már az Európai Közösséghez való csatlakozással, annak elökészítésével és feldolgozásával is szükségszerủvé váltak, megvalósitásuk azonban egyéni és intézményes ellenállásba ütközött.

Kelet-Ausztria névlegesen újra centrális régióvá vált Európában. Összetevői: Burgenland, Alsó-Ausztria és Bécs külön-külön is új helyzet elött állnak, regionális helyzetük új megfogalmazásra szorul. A centrális helyzet azonban csak viszonylagosságában értelmezhető földrajzi adottság. Hasznosítása erőfeszitést igényel, a dinamikusan változó környezet - mindenek elött az Európai Unió és a kelet-közép-európai országok fejlődésének - figyelembevételével valósítható meg. Ezen belül vannak feladatok, amelyeket a keleti tartományoknak - a közöttük versengést okozó tényezők elismerése mellett is - közösen kell megoldaniuk. Így a Keleti Régio (Region Ost) intézményesített együttmüködésének erősítése, annak szervezeti megoldása napirenden van. Ez annál inkább is lényeges, mert a versenyhelyzetet még csak elmélyíti az Európai Közösség regionális politikája. Hiszen az különbséget tesz a régiók fejlesztési, támogatási eszköztára között fejlettségük, határhelyzetük és más egyéb kritériumok szerint.

A régiók nemzetközi versenyében a tartományok között valószínúleg több a közös érdek, mint az ellentét, bár ez utóbbi sem lebecsülendỏ. Ez azonban kimunkálásra szorul. A Keleti Régió (Region Ost) "The Vienna Region" név alatt együttesen kíván fellépni. E stratégia alapja az, hogy Bécs (Wien, Vienna, Vienne), mint helymeghatározó, nemzetközileg nagyobb ismeretségi fokkal rendelkezik, mint 
Fáth János : Kelet-Ausztria az új Közép-Európában.

A jövőkép és az intézményrendszer kérdései.

Tér és Társadalom 11. évf. 1997/1. 271-281. p.

maga Ausztria, nem is beszélve Alsó-Ausztriáról vagy Burgenlandról. További erőssége, hogy közvetlenül és hangsúlyosan az adott térségre utal.

Ez a hangsúlyos szembeállítása az országnak és az országon belüli régiónak csak megszoritással fogadható el. Különösen a beruházók, mint célcsoport számára egy, az ország a maga intézményeivel, jogrendszerével, gazdasági, pénzügyi és politikai stabilitásával, biztonsági politikájával, amely a maguk összességében döntő telepítési tényezők (szemben az egyszerü turista gondolkodásával, aki csak egy látogatást tervez és más prioritásai vannak). Beruházók általában elöbb döntenek az ország mellett és csak azután a régió, a város mellett. Az sem kizárt azonban, hogy a földrajzi helyzet, speciális regionális adottságok hívják fel a figyelmet az országra, amelyhez a célrégió tartozik.

A Vienna Region - mint arra már utaltunk - olyan jövőkép, amelyben a marketing koncepciónak nagy szerepe van. Ezzel is magyarázható, hogy koncepció kidolgozói (WWFF-ECO PLUS-WIBAG 1995) súlyt helyeztek a szomszédos országoknak a "bécsi régió"-hoz közvetlenül kapcsolódó területeinek a meghatározására is. Északon helyezkedik el Dél-Morvaország, 2050 ezer lakossal. Központja a 388 ezer lakosú Brünn. Dél-Csehország lakosainak száma 113 ezer, Budweis-szel, mint fövárossal (173 ezer lakos). Nyugat-Szlovákia lakosainak száma a legutolsó népszámlálás szerint 2154 ezer volt. Az ország lakosságának 41\%-a él ebben a régióban. Pozsony lakosainak száma kereken 441,5 ezer. A lakosság növekedése erőteljesebb például, mint a szomszédos Csehországban. Magyarországból az összesen mintegy 700 ezer lakosú Győr-Moson-Sopron és Vas megyéket sorolják Bécs tágabb régiójába. Így ez az ambiciózusan felvázolt közép-európai centrális régió mintegy 7 millió lakost foglal magába.

A centrális régió kisebb változata a három ország érintkező régiója (KeletAusztria, Nyugat-Szlovákia, Nyugat-Magyarország) mintegy 4 millió lakossal.

A Keleti Régió regionális marketingjének másik nagy irányvonala Brüsszel. Itt a három tartomány ugyancsak közösen kíván fellépni. Brüsszelben és még tágabb nemzetközi összefuiggésben a stratégiai cél a terület aktív ajánlása (Vermarktung) az osztrák Keleti Régió és közvetve, lehetőség és szükségesség szerint, a külfơldi szomszéd régiók fejlődési potenciáljának bemutatásával. A tartományok különkülön is nagy súlyt helyeznek a brüssszeli képviseletre és írásos ismertetőkre (z.B. EU-Länderpräsentationen 1995).

\section{A keleti tartományok kooperációjának intézményei és jövö feltételrendszere}

Kelet-Ausztriában a Keleti Tervközösség (Planungsgemeinschaft Ost - PGO) a legfontosabb koordináló intézmény. E mellett a Közlekedési Egyesülésnek (Verkehrsverbund Ostregion - VOR), a Hulladékgazdálkodási Tervezö Kft-nak (Abfallwirtschaftsverbund-Planungsges $\mathrm{GmbH}$ ) és az Alsó-Ausztria-Bécs Egyesületnek (Verein Niederösterreich-Wien) van koordináló-tervezö szerepe.

PGO-ban mind a három keleti tartomány részt vesz. A területalakitással összefuiggő tevékenységek elökészítésére és koordinálására alakult. Jogi alapja egy, 
a három tartomány között a Szövetségi Alkotmányjogi Törvény 15/a.§-a alapján létrejött 1978. április 18-i megállapodás.

A Közlekedési Egyesülés hatásköre Bécsre, a Bécs városával határos alsóausztriai kerületek (Bezirk) és Burgenland északi részére terjed ki, mintegy 7000 $\mathrm{km} 2$ területen, 2,3 millió lakossal. A többi regionális közlekedési egyesülések Alsó-Ausztriában és Burgenlandban kereken $15000 \mathrm{~km}^{2}-\mathrm{t}$ fognak át 1 millió lakossal.

A Hulladékgazdálkodási Kft-nek nemcsak koordináló szerepe van. Hatáskörébe tartozik közös hulladékgazdálkodási koncepciók kialakítása, telephelyek megvizsgálása, a hulladéktárolók környezetvédelmi felülvizsgálata, a hulladékgy̋̈jtés Bécs és Alsó-Ausztria területén.

$\mathrm{Az}$ Alsó-Ausztria-Bécs Egyesület Bécs környékét $50 \mathrm{~km}$-es hatókörben fogja át a bécsi erdő védelmére és közös üdülési területek kialakítására.

$\mathrm{Az}$ Európai Közösséghez történt csatlakozás és a határnyitás/rendszerváltás a kelet-európai országokban, a keleti tartományok közötti kooperáció jellegének és intézményeinek az újragondolását tette időszerüvé. A kezdeményezők új fejlesztési stratégiák és az együttmüködés új formáinak a kialakítását tartják szuikségesnek (Wiener Regionalkoferenz, 1993; Antalovsky, Sapper, Schadt 1994).

Ezek szerint:

- a Keleti Régiót a központi közép-európai térség (ein Zentralraum für Mitteleuropa) rangjára kell emelni, ennek megfelelő felértékelést szükséges szorgalmazni;

- a Keleti Régiót abba a helyzetbe kell hozni, hogy mint autonóm szereplö léphessen fel régiók közötti versenyben (Akteur im Wettbewerb der Regionen);

- a régió szereplőinek széles körét be kell venni az együttmüködésbe.

Mindhárom cél közelebbi meghatározásra szorul, de úgy valósíthatók meg, ha a regionális-tartományközi együttmüködést nemcsak szakpolitikai és tervezési kihívásként, vagy szükségességként fogják fel, hanem, mint egy kommunikációs feladatot és egy dialógusra épülő projektet.

A kitúzött stratégiai célok - jövőképek - nem egykönnyen valósíthatók meg. A kutatók szerint inkább folyamatokról van szó, amelyeknek bizonyos fejlödési vonalat kell követniük. A folyamat nemcsak racionális felismerésekböl áll. Az intézményeknek és a folyamatoknak egyben a konfliktusok feloldását, az érdekek egyeztetését és kiegyenlítését kell szolgálniuk (Antalovsky, Sapper, Schadt 1994).

A közép-európai központi régió gondolata, mint fentebb láttuk, mind a három tartomány stratégiai önmeghatározásában megtalálható.

A modern kommunikációs terminológia szerint (Huber 1993) itt a következö három, egymással szorosan összefüggő feladat megoldásáról van szó:

- "Schnittstellen-Problematik": a részek között kapcsolatot teremteni és fenntartani;

- "Transfer-Problematik": az erőforrások cseréje a részek között (munkaerö-, tudás-, technológia- és tökemozgás);

- "Formations-Problematik": a mozgási folyamatokhoz szükséges kommunikációs hozzáértés/képesség kifejlesztése egyéni és intézményi szinten. A kommunikációs képesség kialakítása szükségszerü, hiszen a 
Fáth János : Kelet-Ausztria az új Közép-Európában.

A jövőkép és az intézményrendszer kérdései.

Tér és Társadalom 11. évf. 1997/1. 271-281. p.

személyi identitás, a társadalmi integráció, a gazdasági hatékonyság, valamint a politikai stabilitás és összetartozás egy komplex környezetben legyen megvalósitható és fenntartható.

Nem kevésbé összetett feladat a három tartományból összetevődő régiónak, mint új szereplönek a megvalósítása. A régió ebben a szemléletben nemcsak egy térbeli jelenség, hanem egy szereplöje a gazdasági versenynek. Az "értékesítési" funkció hatékony ellátásához egységes fellépés és cselekvőképesség nélkülözhetetlen. Ez csak úgy valósítható meg, ha a részek jól felfogott egyéni érdekböl és nem az intézményileg elöírt kötelességből múködnek együtt.

Közös külföldi marketingben egyezett meg a három tartomány 1995. júniusában "The Vienna Region" név alatt (WWFF-ECO PLUS-WIBAG 1994). A már önálló képviseletekkel rendelkező három tartomány közösen (is) kíván Brüsszelben a beruházók és különféle pénzforrások megnyeréséért (közös lobby) fellépni. Az érvek között szerepel Bécs hídfó funkciója az EU és az új kelet-európai demokráciák között. Burgenland, mint 1. számú célterület a jelentős támogatási lehetőségekre történō hivatkozással egészíti $\mathrm{ki}$ a három tartomány marketingfegyvertárát.

Összetett feladat az érdekeltek széles körben való mozgósitása. Egy állandó regionális tanács felállításával, (alkalmi) fejlesztési bizottságokkal, egy széleskörü regionális információs szolgálattal, közös pénzügyi alapokkal, fejlesztési társaságokkal, vegyes intézményi formák sokoldalú hálózatszerü kialakításával lehetne ezen célt elérni.

Tekintve, hogy három tartomány együttmüködéséről van szó, a célok megvalósitása jelentős politikai feladat is. Az elgondolások szerint a PGO-t a regionális törvényhozás kiegészitö intézményeként kell felértékelni. Itt együtt ülnének a döntéshozók a három tartományból. Egyik elgondolás szerint $10-10$ fövel lennének az egyes tartományok képviselve. Albizottságokban tárgyalnának meg szakproblémákat. Terveznek egy Eurorégió Bécs és Környéke Egyesülést, egészen a bécsi kerületekig, tartományok területén lévő községekig terjedó tagsággal, a különbözö elökészítő/végrehajtó tevékenységek koordinálására.

A nagy települési tengelyek/koncentrációk közös meghatározása, a települési problémák mellett nagy súlyt kap az elgondolásokban a közlekedés összehangolt továbbfejlesztése, különösen Bécs és Alsó-Ausztria (többek között az ingázók) vonatkozásában.

A Keleti-Régióban az együttmüködésnek egyéb intézményi formái is vannak. Ezek között megemlíthetjük a Burgenland, Alsó-Ausztria és Bécs gazdasági kamaráinak az együttmúködését, amit már írásba foglaltak. Ennek fontos pontja a Keleti Régió közös szakmai képviselete, együttes eljárási formák kialakitása Brüsszel és a szomszédos országokkal szemben.

$\mathrm{Az}$ ismertetett elgondolások, mint a térség jövőképe a régióban rejlö lehetőségekből fakad. A jövőképre épülő fejlesztési stratégiához a szervezett tartományok sokszínủ együttmüködésére, a különféle szereplök együttes és összehangolt cselekvésére, valamint az egymás közötti folyamatos és rendszeres kommunikációra van szükség. 
Fáth János : Kelet-Ausztria az új Közép-Európában.

A jövőkép és az intézményrendszer kérdései.

Tér és Társadalom 11. évf. 1997/1. 271-281. p.

\title{
Irodalom
}

Aiginger K. (1993) (Koordination) Chancen und Gefăhrdungspotentiale der Ostöffnung: Konsequenzen für die österreichische Wirtschaft, Teil I-II, Studie des Österreichischen Instituts für Wirtschaftsforschung (WIFO) im Auftrag der Bundeswirtschaftskammer und des BM für wirtschaftliche Angelegenheiten, Wien,. 135 o.

Antalovsky, Sapper, Schadt (1994) Organisationsaspekte regionaler Kooperation Studie des Kommunalwissenschaftlichen Dokumentationszentrums für Wien, für Niederösterreich und für das Burgenland, 147 o.

Geldner N. (1993) Beschäftigungseffekte der Grenzöffnung (im Bericht Aiginger, wie oben). Wien.

Huber J. (1993) Regionalentwicklung in der Kommunikationsgesellschaft. Westdeutscher Verlag. Opladen, 2880.

Institut für Gewerbe- und Handwerksforschung: West-Ost Erfahrungstransfer, Regionalprojekt OstÖsterreich, West-Slowakei, West-Ungarn. IfG Mitteilungen, I. Hj. (Szerk.: Fath, J., I. Fröhlich). Wien.

Geldner N. (1993) Beschäftigungseffekte der Grenzöffnung (im Bericht Aiginger). Wien.

Krajasits C. (1992) Der Raum Wien-Bratislava: Modellfall für eine Regionalpolitik offener Grenzen, RAUMOsterreichische Zeitschrift für Raumplanung und Regionalpolitik. Wien, 27-28. o.

Magistrat der Stadt Wien, Abt. Stadtentwicklung und Stadtplanung: Stadtentwicklungsplan für Wien. Step 1994, Wien.

Mayerhofer P. (1994) Wirtschaftsförderung in Wien, Probleme und Reformvorschläge unter Berücksichtigung der neuen geopolitischen Rahmenbedingungen. Studie des Österreichischen Instituts für Wirtschaftsforschung (WIFO) 224. o.

Mayerhofer P. (1992) Wien im neuen Mitteleuropa. Ökonomische Effekte der Ostoffnung. WIFOStudie.

Palme G. (1993) Wirtschaftspolitische Perspektiven, Niederösterreich in den 90-er Jahren, Ansatz zu einer modernen Industrie- und Regionalpolitik. (Studie im Auftrag der Landesregierung der Wirtschaftskammer N.OO.) 135. o.

Puchinger, Palme, Rosinak (1994) Modellbearbeitung Regionalwirtschaftiches Konzept Burgenland. Österreichische Raumordnungskonferenc, Schriftenreihe Nr. 113. Wien.

Planungsgemeinschaft Ost - PGO (Burgenland, N.-Österreich, Wien): Tätigkeitsbericht 1993. Berichte 2/1994. Wien. 52 o.

Porter M. E. (1992) The Competitive Advantage of Nations, The Macmillan Press.

Schremmer, Krajasits (1992) Szenarien zu Ost-Grenzöffnung und deren Auswirkungen auf die österreichischen Ost-Grenzregionen. ÖIR Wien. 123 o.

Thurow L. (1995) The future of Capitalism: How Todays's Economic Forces Shape Tomorrow's World, William Morrow.

WWFF/ECO PLUS/BIWAG: Wirtschaftsstandort Region Wien, 1995.

Wiener Regionalkonferenz - der Kleine und der Große Horizont. Dokumentation der Fachtagung vom 23. Juni 1993. Verleger: Kammer fur Arbeiter und Angestellte für Wien. 1993. 67 o.

\section{EAST AUSTRIA IN THE NEW CENTRAL EUROPE - PROSPECTS AND INSTITUTIONAL SYSTEM}

\author{
DR. JÁNOS FATH
}

The essay deals with the efforts of the eastern provinces of Austria (Vienna, Upper Austria and Burgenland) to define their places, with special regard to the new geopolitical conditions. One of the means for that, which mostly comes from research and political forums, is the creation of a prospect for the future. The author 
examines the prospects at three levels, i.e. province, East-Austrian region and interregional, beyond-border levels.

The prospect projects the future situation of the region from the analysis of the inner forces and the environmental changes. From the future prospects we can derive the measures that need to be taken. On each level, institutions and conditions are needed which promote and allow the utilisation of the opportunities. The joint operation and joint decision making processes of the east Austrian provinces have only been accomplished in some partial fields.

The future prospects of the provinces place special emphasis on wider regional connections reaching beyond the borders. The objective is to have in the future a Central European region which is not only a geographical but also an economic reality. 